\title{
Land use and land cover dynamics and traditional agroforestry practices in Wonchi District, Ethiopia
}

\author{
Misganaw Meragiaw ${ }^{\text {Corresp., } 1}$, Zerihun Woldu ${ }^{1}$, Bal Ram Singh ${ }^{2}$ \\ ${ }^{1}$ Department of Plant Biology \& Biodiversity Management/College of Natural and Computational Sciences, Addis Ababa University, Addis Ababa, Ethiopia \\ ${ }^{2}$ Faculty of Environmental Sciences and Natural Resource Management, Norwegian University of Life Sciences, Ås, Norway \\ Corresponding Author: Misganaw Meragiaw \\ Email address: misganaw.meragiaw@aau.edu.et
}

Background. Investigating the land use and land cover (LULC) dynamics and the status of traditional agroforestry practices provide important data for policymakers. The main objective of this study was to assess the LULC dynamics and traditional agroforestry practices among smallholder farmers across the two agro-ecological zones in Wonchi District of Ethiopia.

Methods. Landsat images were acquired from Earth Explorer, and changes in LULC were quantified with three Landsat sensors in the three time-series $(1985,2001$, and 2019). Supervised classification with maximum likelihood technique was employed using ERDAS Imagine and ArcGIS. A ground survey was conducted with 100 key informants who were selected from 10 sites using a purposive sampling method. The collected data were subjected to direct matrix ranking, use-value analysis of most important multipurpose plant species, and semi-structured interviews were conducted for qualitative analysis.

Results. In total, 103 agroforestry plant species belonging to 44 families were identified in Wonchi District, of which 74 were indigenous including seven endemic and 29 exotic species. The highest species (13) were recorded in the Fabaceae family. About $61 \%$ of species were reported in the midland agroecological zone. A mixed farming system was the most frequently (56\%) reported source of income. The results of LULC changes from 1985 to 2019 showed that the agroforestry cover increased from $31.1 \%$ to $34.9 \%$ and settlement including road construction increased from $12.5 \%$ to $31.6 \%$ of the total area with an annual rate change of $0.3 \%$ and $2.7 \%$, respectively. These changes corresponded with a decreasing trend of the forest, cropland, water body, and shrub at a rate of $4.7 \%, 1.3 \%, 0.8 \%$, and $0.5 \%$, respectively. The LULC changes were more pronounced in the highlands than in the midlands of Wonchi District. Expansion of settlement and tenure policy change are the main drivers for these changes in the area. The authors recommended that protecting and planting indigenous and multipurpose plant species is essential as restoration techniques for all degraded land-use types. Therefore, strengthening agroforestry practices and land-use planning is urgently needed for achieving multiple goals. 
1 Land use and land cover dynamics and traditional agroforestry practices in Wonchi

2 District, Ethiopia

3 Misganaw Meragiaw ${ }^{1}$, Zerihun Woldu ${ }^{1}$, Bal Ram Singh ${ }^{2}$

$4{ }^{1}$ Department of Plant Biology \& Biodiversity Management, College of Natural and Computational Sciences, Addis

5 Ababa University, Addis Ababa, Ethiopia

$6{ }^{2}$ Faculty of Environmental Sciences and Natural Resource Management, Norwegian University of Life Sciences,

7 Ås, Norway

8 Corresponding author: Misganaw Meragiaw ${ }^{1}$

9 4killo King George VI St, National Herbarium, Addis Ababa, P. O. Box 3434, Ethiopia

10 Email address: misganaw.meragiaw@aau.edu.et

11 Abstract

12

Background. Investigating the land use and land cover (LULC) dynamics and the status of traditional agroforestry practices provide important data for policymakers. The main objective of this study was to assess the LULC dynamics and traditional agroforestry practices among smallholder farmers across the two agro-ecological zones in Wonchi District of Ethiopia.

Methods. Landsat images were acquired from Earth Explorer, and changes in LULC were quantified with three Landsat sensors in the three time-series (1985, 2001, and 2019). Supervised classification with maximum likelihood technique was employed using ERDAS Imagine and ArcGIS. A ground survey was conducted with 100 key informants who were selected from 10 sites using a purposive sampling method. The collected data were subjected to direct matrix ranking, use-value analysis of most important multipurpose plant species, and semi-structured interviews were conducted for qualitative analysis.

Results. In total, 103 agroforestry plant species belonging to 44 families were identified in Wonchi District, of which 74 were indigenous including seven endemic and 29 exotic species. The highest species (13) were recorded in the Fabaceae family. About $61 \%$ of species were reported in the midland agroecological zone. A mixed farming system was the most frequently (56\%) reported source of income. The results of LULC changes from 1985 to 2019 showed that the agroforestry cover increased from $31.1 \%$ to $34.9 \%$ and settlement including road construction increased from $12.5 \%$ to $31.6 \%$ of the total area with an annual rate change of $0.3 \%$ and $2.7 \%$, respectively. These changes corresponded with a decreasing trend of the forest, cropland, water body, and shrub at a rate of $4.7 \%, 1.3 \%, 0.8 \%$, and $0.5 \%$, respectively. The LULC changes were more pronounced in the highlands than in the midlands of Wonchi District. Expansion of settlement and tenure policy change are the main drivers for these changes in the area. The authors recommended that protecting and planting indigenous and multipurpose plant species is essential as restoration techniques for all degraded land-use types. Therefore, strengthening agroforestry practices and land-use planning is urgently needed for achieving multiple goals. 
35

36

\section{Introduction}

Land use and land cover (hereafter called LULC) dynamics provide important data for the policymakers to reconcile forest management practice and crop cultivation in the agroforestry landscape (Pareta and Pareta, 2011; NCDC, 2013). In a broad sense of ecosystem, land refers to landforms, climate, edaphic characters, plants, and water resources. Changes in LULC date back to prehistory and are the direct and indirect consequence of human activities on the integrating elements of these resources (EPA, 1999; Wulder et al., 2016). The negative change contributes significantly to the loss of biodiversity and adverse climate change, mainly due to the conversion of forest cover to agricultural land, human settlement, and infrastructure (FC, 2011; Duguma et al., 2019). Human activity has affected approximately $75-83 \%$ of the global terrestrial land surface and has degraded about $60 \%$ of the ecosystem services throughout time and the human footprint has increased by just 9\% (Zeledon and Kelly, 2009; SD21, 2012; Venter et al., 2016). This change could have first occurred with the burning of vegetation areas to enhance the birth of agriculture, resulting in the extensive deforestation and degradation of Earth's terrestrial surface that continues today with a greater magnitude and rate throughout the world (FAO, 2005; Arevalo et al. 2011; NCDC, 2013; Brown, et al., 2014). This is a primary concern in the second populated country of Africa where the plant resources are gradually declining in many parts of Ethiopia (Moges, Eshetu \& Nune, 2010; Mahoo et al., 2013; Gedefaw et al., 2014).

The LULC dynamics coupled with the increasing human population are affecting global atmospheric concentrations of greenhouse gas (GHG) in different ways (Albrecht and Kandji, 2003; Bălteanu et al., 2013). The primary sources of increasing $\mathrm{CO}_{2}$ related to land use have been the conversion of natural vegetation, shrub, and wetlands to agricultural land and settlements, which has been exacerbated by road construction and other infrastructures ( $E P A$ 1999; FAO 2004; Ali et al., 2011; Menker and Hassan, 2011). The changes in LULC together with changing climatic conditions and policy strategies have caused serious problems in east Africa (Lemenih 2006; Mahoo et al. 2013). Subsequent policy changes in Ethiopia have led to the illegal destruction of protected forests and shrubs for settlement and farming land (WBISPP, 2005; Birhanu et al. 2019).

Understanding the status of LULC is vital for the selection and the possibilities for optimal use of land-use types to meet the increasing demands for basic human needs in harmony with environmental protection (Pareta and Pareta, 2011; Rawat and Kumar, 2015). A combination of 
crop and farming trees in agroforestry land-use type typically provides to mitigate climate change and deliver countless outcomes in ecological, economic, and social services (FAO, 2011a; FAO 2011b; Smith et al., 2012; Mbow et al., 2014; Meragiaw, 2017; Helen, Jarzebski \& Gasparatos, 2019). However, this aspect needs more research work in Ethiopia to find a high yield of crop production in tree-based farming strategies in different agro-ecological zones. Nationwide, the association of the local community and scientific knowledge plays a greater role in forest conservation, and traditional agroforestry management practices (Moges, Eshetu \& Nune, 2010; Asfaw and Lemenih, 2010; Reubens et al., 2011; Meragiaw, 2017). Moreover, the intentional conservation of plant diversity in traditional agroforestry systems could partly compensate for the continuing deforestation in a less protected forest (Asfaw and Lemenih, 2010). Wonchi District has diverse land-use types and, agro-ecological and biophysical situations with considerable numbers of endemic plant species (Meragiaw et al., 2018; Meragiaw et al., 2021a; Meragiaw et al., 2021b). Information on LULC change status and identifying the driving force behind this change are essential for designing sound environmental protection and community-based agroforestry management practices. However, the baseline information on LULC and the traditional agroforestry system is poorly documented in Ethiopia and is still lacking across the two agro-ecological zones of Wonchi District. Thus, the present study was conducted to address the following research questions: (1) Are the current agroforestry and crop species taxonomically diverse in Wonchi District? (2) Is there a difference between highland and midland agro-ecological zones in agroforestry practices and species distribution over the three decades? (3) Is there a significant change detection in land-use types in Wonchi District in the past 34 years? and (4) Are there major change drivers in the two agro-ecological zones?

Taking these questions in mind, we aimed to: (i) identify agroforestry multipurpose and crop species in the two agro-ecological zones of Wonchi District; (ii) assess the status of traditional agroforestry systems across the two agro-ecological zones; (iii) analyze the spatial and temporal LULC dynamics using Landsat images for 1985, 2001, and 2019; and (iv) examine the main driving forces for the change and suggest possible management practices.

Materials \& Methods

Description of the study area 
96 The present study was conducted in Wonchi District, Southwest Shewa Zone in the Central

97 Highland of Ethiopia (Fig. 1). The area of the district is representative of diverse land-use types.

98 Wonchi District is near the geographical coordinates at $8^{\circ} 46^{\prime} 30.1908^{\prime \prime}-8^{\circ} 47^{\prime} 36.7584^{\prime \prime} \mathrm{N}$ and

$9937^{\circ} 51^{\prime} 53.8524^{\prime \prime}-37^{\circ} 54^{\prime} 19.0152^{\prime \prime} \mathrm{E}$, and the altitude ranges from 1700 to $3387 \mathrm{~m}$ a.s.l. Wonchi

100 District has 22 rural and two urban kebeles (smallest administrative units) within two agro-

101 ecological zones (Meragiaw et al., 2018). Based on the Central Statistical Agency (CSA, 2008)

102 data, the total projected population of the district was about 163, 658 in 2019.

103 According to MOA (2000) agro-ecological classification systems, Wonchi District can be

104 classified into highland and midland agro-ecological zones. The study area had a unimodal

105 rainfall distribution with $1030 \mathrm{~mm}$ (at Ambo) up to $1160 \mathrm{~mm}$ (at Woliso) of mean annual rainfall

106 from 2004 to 2015 . The mean annual temperature was $19.2-19.3{ }^{\circ} \mathrm{C}$ with a minimum of $10.9-12$

$107{ }^{\circ} \mathrm{C}$ and a maximum of 28.0-28.8 ${ }^{\circ} \mathrm{C}$ (Meragiaw et al. 2021a; Meragiaw et al., 2021b).

108 The vegetation of the study area is characterized by dry evergreen montane forest and sub-

109 afro-alpine vegetation at the peak of Kibate Forest, riparian vegetation in Walga and Amegna

110 rivers, and natural woodlands including shrubs and grasses. However, the vegetation is widely

111 encroached by an expansion of farmlands to steep hills, increasing demands on forests for

112 various purposes, settlements, and infrastructural development (Friis, Demissew \& Breugel,

113 2010; Meragiaw et al., 2018; Meragiaw et al. 2021a; Meragiaw et al. 2021b). Wonchi Crater

114 Lake is surrounded by the Kibate Forest that is a major tributary of Walga River and the source

115 of the Gibe River watershed (Meragiaw et al., 2021a). The surrounding flora and fauna attract

116 many tourists so that the Ethiopian government has recently initiated the development of eco-

117 tourism and a recreational center through the "dine for the nation" project.

\section{Data collection methods}

119 A reconnaissance survey was conducted to identify potential study sites. Our research was 120 carried out in the upper Gibe watershed ecosystem of Wonchi District from March 15 to April

121 15, 2019. Specific permission was not required to conduct this study since it did not involve the

122 extraction of endangered species. However, a permit was obtained from the Wonchi District

123 Agricultural and Rural Development Office for data collections of LULC and traditional

124 agroforestry practices based on the supporting letter of Addis Ababa University provided at the

125 beginning of the research project (approval reference number: DPBBM/CNCS2471/10/2017). Of 
126 the total 24 kebeles (hereafter called sites) of the district, 10 representative sites were selected

127 using a stratified sampling technique following altitude gradients (Fig. 1). The selected sites

128 included 20 villages and wide altitude ranges of 1997 (in Degoye Galle site) to 3290 m a.s.l. (in

129 Harro Wonchi site). Five sites were selected in both highland and midland agro-ecological zones.

130 The ground survey was also conducted with 100 informants who were selected using a purposive 131 sampling technique based on their ground knowledge about the traditional agroforestry practices

132 and the historical land-use changes by the endorsement/direction of local administrative leaders

133 and elders following ethnobotanical methods. The data was collected through semi-structured

134 interviews and focus group discussions for qualitative analysis. Ten informants aged greater than

13529 years including both sexes participated in each site (Fig. S1).

\section{Botanical methods}

137 The plant specimens were identified in the field using taxonomic keys of different volumes (1-7)

138 of Flora of Ethiopia and Eritrea. Additionally, we have used other sources (Kyalangalilwa et al., 139 2013) for the revised taxonomy of Vachellia (formerly known as Acacia). The photographs of 140 unknown species were collected to compare with voucher specimens at the National Herbarium 141 of Ethiopia. Most of the wild plant species had already been collected in the previous research 142 works for other objectives by different aims with the same authors in the same project area 143 (Meragiaw et al., 2018; Meragiaw et al., 2021a; Meragiaw et al., 2021b) and the other domestic 144 crop species are common staple foods throughout the country.

\section{Demographic information of informants in the two agro-ecological zones}

All informants were married, aged 29 years old and above, and residents in the area. The total family size of informants ranged from 2 to 18 with an average of 7 people in one household. Based on the three age groups, the highest number of informants (47\%) was found in the young age group (30-39). Both males and females participated in this study, but a larger number of informants $(59 \%)$ were males. About $35 \%$ of the total informants could not read and write while the least number of informants were found at a higher level of education above grade 12 and above. Most of the female informants were illiterate, in comparison to males. The demographic

153 features of the informants are summarized in Table S1. 


\section{Satellite data acquisition and image pre-processing}

155 Besides historical evidence of ground survey from the collected data through questionnaires, 156 Landsat images of the three time-series (1985, 2001, and 2019) with different Landsat sensors

157 (thematic mapper, enhanced thematic mapper, and operational land imager) and IDs (5, 7, and 8)

158 were acquired from the Earth Explorer free data provider website

159 (https://earthexplorer.usgs.gov/) of the United States Geological Survey (USGS). All images

160 were downloaded from the end of October to the beginning of January for each of the three time161 series at the time of a low cloud cover (0.5-1\%) season for high-quality images of the land-use 162 types. Each of the Landsat images was with a raw 054 and a path 169 . These data had $30 \mathrm{~m}$ 163 spatial resolution and Universal Transverse Mercator (UTM) projection system with Zone $37 \mathrm{~N}$ 164 and Datum of World Geodetic System 1984 (WGS84) to maintain consistency between datasets 165 during analysis. These data sets were imported in satellite image processing software, ERDAS 166 Imagine 2015 version 15.0. The layer stack option in the image interpreter toolbox was used to 167 generate false-color composites for the study areas. Satellite image subsetting was performed for 168 169 extracting the delineated study area from all images by taking a georeferenced outline boundary of the Wonchi District shapefile map as an area of interest (AOI) following Weng (2010). The coordinate system of the image and vector data in the shapefile was overlaid to the raster image and georeferenced using the UTM projection type. Thus, the alignment of the two images was verified following Yahya, Mulat \& Getachew (2019). As shown in the ground survey report, the sets of time-series were selected based on major changes shown in Ethiopia in general and in the study area, relating to an increasing population and subsequent policy shifts with regime change. Table 1 shows the details for the three acquired satellite images.

\section{Data analysis}

177 Both qualitative (informants' suggestions for open-ended questionnaires in semi-structured 178 interviews) and quantitative data were collected and subjected to direct matrix ranking and use 179 value analysis. Direct matrix ranking was performed to compare multipurpose plant species 180 following Cotton (1996). The use-value analysis was also conducted for plant species that have two or more use-values. It was applied to measure average reports of uses informants know for a 182 species. The use-value was calculated following Cunningham (2001): 
184 where $U_{\text {is }}=$ Use value attributed to a species (s) by one informant (i), $n_{i}=$ Total number of

185 informants interviewed for species $\mathrm{s}$, and $\Sigma=$ Sum the informant use values for a species divided 186 by the total number of informants.

\section{LULC image classification}

188 For LULC classification, a supervised classification method with a maximum likelihood 189 algorithm (MLC) was applied. The MLC is one of the most popular supervised classification 190 methods used with remote sensing image data. This method is based on the probability that a 191 pixel belongs to a class (FAO, 2005; Yahya et al., 2019). The LULC images of the study area 192 from 1985 to 2019 over 34 years were quantified and analyzed in six different classes. The six 193 land-use types are agroforestry cover, cropland, forest cover, shrub cover, water body, and 194 settlement and roads (Table S2).

\section{Classification of accuracy assessment}

196

197

198

199

200

201

202

203

204

205

206

207

208

209

210

211

212

Accuracy assessment was carried out to determine if the produced classification is compatible with the definite land cover conditions obtained from their corresponding ground truth data following Rwanga \& Ndambuki (2017). The error matrix and Kappa statistic were used to assess the mapping accuracy following Pelton, Madry \&Camacho-Lara (2013). In the present study, the accuracy was assessed using sample point data as a reference from corresponding Google Earth images for the three time-series of 1985, 2001, and 2019. Thus, the ground verification was done for doubtful and misclassified areas using the recode option. Accordingly, the validation points for three years ranging from 217 to 343 were generated in the classification of the study area. Consequently, the classified images were compared with reference images by using error matrices. Producers' and users' accuracies are ways of representing individual class accuracies based on commission errors (including an area that does not belong to the class) and omission errors (excluding an area from the category to which it belongs). According to Congalton (1991), an error matrix is an effective way of computing user's accuracy (row total shows the sample points generated from the map), producer's accuracy (column total that represents the reference data), and overall accuracy (the sum of correctly classified samples in the major diagonal divided by the total number of samples in the matrix). A nonparametric Kappa statistic test was also performed to measure the extent of classification accuracy that 
213 accounts for all the elements in the confusion matrix including diagonal elements following

214 Hassan et al. (2016).

$215 \hat{\mathrm{K}}=\left(N \sum_{i=1}^{r} x_{i i}-\sum_{i=1}^{r}\left(x_{i+} * x_{+i}\right)\right) /\left(\mathrm{N}^{2}-\sum_{i=1}^{r}\left(x_{i+} * x_{+i}\right)\right) \ldots \ldots \ldots \ldots \ldots \ldots \ldots . . . . . . . . .2$

216 where $\hat{K}=$ Kappa statistic, $\mathrm{N}=$ total number of observations (pixels) in the error matrix, $\mathrm{r}=$

217 number of rows, columns in the error matrix, $x_{i i}=$ number of observations in row $i$ and column $i$

218 (major diagonal element for class $i$ ), $x_{i^{+}}=$the total number of observations in row $i$ (right margin

219 of the matrix), and $\times_{+\mathrm{i}}=$ total number of observations in column $\mathrm{i}$ (bottom marginal of the 220 matrix).

221

222

223

224

225

226

227

228

229

230

231

232

233

234

235

236

237

238

\section{LULC change detection in the classified images}

Classified image pairs of two different period data were compared using cross-tabulation to determine qualitative and quantitative aspects of the changes from 1985 to 2019 in more than three decades. A change matrix was produced using ERDAS Imagine 2015 and georeferenced with ArcGIS 10.4.1 as previously done by Weng (2001). Quantitative data of the overall LULC changes as well as gains and losses in each category between two periods were compiled. For performing LULC change detection, a post-classification comparison technique was used for extracting quantitatively the conversions between the various LULC classes and deducing the LULC change rates (Hassan et al., 2010). The land-use conversion matrices were generated for 1985, 2001, and 2019 and turned to a matrix table with area in ha. The annual rate of change of the various classes was also calculated following Malaviya et al. (2010) and Puyravaud (2003).

The annual rate of LULC change $(r)=\left(\left(\frac{1}{t_{2}-t_{1}}\right) \ln \left(\frac{A_{2}}{A_{1}}\right)\right) * 100 \ldots \ldots \ldots \ldots \ldots \ldots$ Eq. 3

where $r$ is the rate of land cover change detection, and $A_{1}$ and $A_{2}$ are the areas of LULC at time $t_{1}$ and $t_{2}$, respectively. A positive value indicates an increase whereas a negative value shows a decrease in the extent of LULC changes.

\section{Results}

Taxonomic diversity of plant species and traditional agroforestry practices in the study area 
239 In total, 103 agroforestry plant species belonging to 44 different families were identified in

240 Wonchi District, of which 41 were crop species and 62 were multipurpose species. The highest

241 number of species (13) was recorded in the Fabaceae family, followed by Poaceae (11 species).

242 Based on species that originated in the flora area, 74 indigenous including seven endemic and 29

243 exotic species were determined in the study area. All exotic species are crop species except

244 Eucalyptus globulus and three bamboo species. The complete list of species with authority

245 names is presented in Table S3. Regarding species-habitat distribution, 25 species were found in

246 cropland and homegarden (including agroforestry areas nearby settlements), 15 were found in

247 forest patches and shrubs including grazing lands, and 17 species were restricted only in

248 homegarden. More than one-fourth (26\%) of the species were found in three habitats but only 12

249 species including Vachellia abyssinica, Arundinaria alpina, Cordia africana, Croton

250 macrostachyus, Erythrina brucei, Hagenia abyssinica, Hypericum revolutum, Juniperus procera,

251 Myrica salicifolia, Olea europaea subsp. cuspidata, Podocarpus falcatus and Vernonia

252 auriculifera occurred in all habitats (cropland, homegarden, shrub, and forest patches).

253 Regarding species-site distribution, $28 \%$ of the species were distributed in more than two sites

254 and 15 species including Vachellia abyssinica, Allium cepa, Capsicum sp., Cicer arietinum,

255 Ensete ventricosum, Eragrostis tef, Eucalyptus globulus, Hordeum vulgare, Justicia

256 schimperiana, Linum usitatissimum, Ocimum lamiifolium, Rosa abyssinica, Rumex nervosus,

257 Solanum tuberosum and Triticum aestivum were reported in all sites in the study area. Of the

258 total species, $61 \%$ of species were reported in the midland agro-ecological zone. Results show

259 that $98 \%$ of informants reported that they practiced mixed farming of crop and livestock,

260 followed by that in combination with beehives (77\%) and other sources of income (26\%). The

261 details of various aspects of the natural resources of the district are presented in Table S4.

262

263

264

265

266

267

268

\section{Taxonomic diversity of crop species in the two agro-ecological zones of Wonchi District}

The major sources of income in the two agro-ecological zones of the district were crops, livestock production, and other types of income. The livestock production included sheep, goat, and cattle production and sale, cow's milk production and sale, fattening oxen for marketing, and pack animals for carrying loads and sale. Similarly, other types of income include firewood sales, renting land, labor in construction and harvesting crops, and employees in government offices. Crop species are grouped into oilseed, vegetable, cereal, legume, and tree crops, of 
269 which most of the species were distributed in the midland (Table 2). Of the total number of

270 species, 41 crop species belonging to 37 genera and 21 families were identified in the study area.

271 Poaceae (7 species) and Fabaceae (6 species) families were represented by the highest numbers

272 of species, followed by Solanaceae ( 4 species) and Rutaceae ( 3 species). Four families each were

273 represented by two species whereas the remaining 13 families were represented only by one

274 species each. Of the total species, four species for cereal and legume species, five species for

275 vegetables, and eight species for tree crops were recorded only in the midland agro-ecological

276 zone of Wonchi District. By far the most important staple crops grown in the study area are

277 Ensete ventricosum (enset), Eragrostis tef(teff), Solanum tuberosum (potato), Hordeum vulgare

278 (barley), Triticum aestivum (wheat), and Zea mays (maize).

279 Main sources of income across the two agro-ecological zones

280 The district sources of income are mixed with different farming systems (such as crops,

281 livestock, and beekeeping) and local trade mechanisms using shops in town and along the main

282 street. Crop and livestock production (mixed farming) and off-farm sources (beehives and local

283 trade) are generally the main economic activities while the frequencies vary among the 10 sites.

284 The most frequently used farming system (56\%) was mixed farming of crop-livestock-

285 beekeeping system while others such as labor and employment were the least frequently counted

286 for informants. The distribution of the main source of income across the two agro-ecological

287 zones is presented in Table S5.

288 Taxonomic diversity of multipurpose plant species in traditional agroforestry systems of

\section{Wonchi District}

290 Multipurpose plant species were commonly found in the area including natural and plantation

291 forest patches, croplands, shrubs, swamps, and at the edge of the water body. Among the

292 multipurpose tree species, agroforestry trees including crop trees, nitrogen-fixing trees, and

293 fodder trees were planted in the study area. In addition to crop species, 62 multipurpose plant

294 species belonging to 57 genera and 33 families were grown naturally and/or through plantation

295 programs in all sites of Wonchi District. Fabaceae was represented by the highest number of

296 species (8 species), followed by Asteraceae (6 species), Rosaceae (4 species), and Euphorbiaceae

297 and Myrtaceae with three species each. Seven families each were represented by two species. 
298 The remaining 21 families were represented only by one species each (Table S3). Most species

299 were reported in the midland agro-ecological zone. However, nine species reported only in the

300 highland agro-ecological zone were Hagenia abyssinica, Agarista salicifolia, Arundinaria

301 alpina, Echinops longisetus, Hypericum revolutum, Ilex mitis, Inula confertiflora, Conyza

302 hypoleuca, and Myrsine melanophloeos.

303 The common multipurpose agroforestry plant species reported by informants were cited for

304 ecological, economic, traditional medicine, and socio-cultural values. Informants reported that

305 the most common uses of multipurpose plant species were local medicine, wild edible food,

306 charcoal and firewood, shade, live fence, maintaining soil fertility, house construction, and farm

307 tools. Of the seven multipurpose plant species, Cordia africana was the most important species

308 in the collective use category, being followed by Hagenia abyssinica while Carissa spinarum

309 was the least ranked species (Table 3).

310 The major uses including local medicine, wild edible, fodder, soil fertility and maintaining

311 stream shade and live fences, charcoal and firewood, timber, construction, and house furniture

312 were considered to analyze use values of multipurpose plant species. Fifteen multipurpose tree

313 species that have more than two uses were selected. The present study shows that Vachellia

314 abyssinica was the most important multipurpose plant species and ranked first, being followed

315 by Hagenia abyssinica, and Juniperus procera. Erythrina brucei was the least important

316 multipurpose plant among the top 15 species (Table 4).

317 Threats to and current status of natural resources in the study area

318 Although the distribution of natural forest was very limited in the district, about $68 \%$ of the

319 informants cited some forest patches such as Kibate Forest in Harro Wonchi, Kabo Forest in Dae

320 Wandimtu, Arebekuri Forest in Sonko Lekake, Hura Agamisa Forest, and riparian vegetation

321 along Walga and Delena rivers in Degoye Galle. Table S4 indicates that approximately $97 \%$ of

322 the informants perceived that there have been visible changes in LULC types over the last 34

323 years. Accordingly, $71 \%$ of informants agreed on the conversion of forest to agroforestry cover,

324 being followed by forest to settlement (67\%) and shrub cover to cropland (55\%). Likewise, most

325 of the informants (94\%) thought that the conversion of forest into monoculture farming and

326 settlement has negative effects on natural forest resources and causes the scarcity of plant

327 resources to the local community. 
328

329

330

331

332

333

334

335

336

337

338

339

340

341

342

343

344

345

346

347

348

349

350

351

352

353

354

355

356

Regarding the current status of vegetation, $76 \%$ of informants recognized that the natural forest cover has been slightly reduced whereas $22 \%$ of informants reported that it has been degraded severely since the last two governmental regimes. Regarding the set of time-series for the visible reduction of forest cover, the majority of the informants $(77 \%)$ responded that visible changes took place in the current governmental regime with a rapid rate of population growth and expansion of agricultural land whereas $20 \%$ of the informants responded that changes related to loss of taboo for forest protection, as well as 'land to the tiller' policy of land during the Derg regime. The threats of anthropogenic impacts varied from site to site. However, the majority of informants (88\%) reported that expansion of agricultural land was ranked first, followed by charcoal and firewood (69\%), cutting woody species for construction and house furniture (49\%), and overgrazing by livestock (45\%), which is aggravated by a rapid rate of population growth (Table 4). The degradation of natural forests could result in soil erosion, loss of keystone plant species and wildlife, drying of streams, and micro-climate change.

\section{LULC change matrix and accuracy assessment in Wonchi District}

The post-classification of accuracy assessment showed that the overall user's accuracy for the classified images of 1985, 2001, and 2019 years was 96.5, 91.7, and 93.3\%, respectively. The highest (100\%) producer's accuracy of the individual class was recorded for forest cover in 1985, for settlement in 1985 and 2019, and water in 2001 and 2019 whereas the lowest (85.0\%) was reported for cropland in 2019. The user's accuracy for the classified maps ranged from 88.0 to $100 \%$. The Kappa statistic for the three study years of 1985, 2001, and 2019 was 0.96, 0.90, and 0.92 , respectively. The details of the confusion matrix for the classified images are presented in Table 5.

The results obtained through the analysis of multispectral satellite images showed six land-use categories. The total land area of Wonchi District was 46,736 ha. Of the total land area, cropland covered the highest area for 1985 (18,082 ha) and 2001(16,636 ha) years, followed by agroforestry cover (ca. 31\%) in both years. However, agroforestry accounted for the highest area (16,305 ha), followed by settlement and infrastructure (14,753 ha) for the 2019 year (Table S6).

The three satellite images are diagrammatically illustrated in Fig. 2.

\section{LULC status and comparison of changes between study periods}


357 The analysis of LULC change status showed that agroforestry cover was the predominant land358 use type throughout the study periods (1985, 2001, and 2019), covering $31.1 \%, 31.4 \%$, and $35934.9 \%$ of the study area, respectively. Conversely, the water body was the least dominant LULC 360 type throughout the study periods. In the current status (2019), the highest area was covered by

361

362

363

364

365

366

367

368

369

370

371

372

373

374

375

376

377

378

379

380

381

382

383

384 agroforestry (34.9\%), followed by settlement and roads (31.6\%) and cropland (24.8\%). In the previous years, cropland and agroforestry cover occupied the highest percentage of land cover with 38.7\% (1985) and 35.6\% (2001), and 31.1\% (1985) and 31.4\% (2001), respectively. Areas of all classes for Landsat images of 1985, 2001, and 2019 are summarized in Table S5.

The analysis of LULC change between 1985 and 2001 years indicated an increase in area coverage for shrub and agroforestry, while the second and the third comparison periods (20012019 and 1985-2019) showed an increase for agroforestry cover and settlement, but a decrease for cropland, forest cover, shrub cover, and water body. The percentage area changes show that the agroforestry cover and settlement including road infrastructure increased from 1985 to 2019 while the other LULC types declined from 1985 to 2019. Table 6 shows the area change in different land categories.

\section{LULC change detection}

The annual rate of increase between 1985 and 2019 for settlement and roads, and agroforestry cover was $2.7 \%$ and $0.3 \%$, respectively. The annual rate of decrease in forest cover, shrub cover, water body, and croplands was $4.7 \%, 1.3 \%, 0.8 \%$, and $0.5 \%$, respectively. Thus, the overall LULC change detection showed a loss of land size in four of the LULC classes and a gain of land size in two of them. Even though the level of changes varied among the LULC types, the highest annual rate of change was recorded in forest cover (lost), followed by settlement and road construction (gained) between 2001-2019 and 1985-2019, and shrub cover also between 1985-2001 and 2001-2019. The agroforestry cover never declines whereas forest cover and open field croplands decrease in all three time-series (Fig. 3).

\section{Discussion}

LULC change and traditional agroforestry practices in Wonchi District and implication for climate change mitigation 
385 Despite the prevalence of anthropogenic disturbances, the two agro-ecological zones still harbor 386 a relatively high number of crop and multipurpose species (103) is a good indication that the area 387 has a reasonable number of useful agroforestry species including endemic species. Agroforestry 388 is a tree-based farming practice that allows the integration of useful trees with annual crops in a 389 common rural land management practice across agro-ecological landscapes in Africa (Mbow et 390 al., 2014). In traditional agroforestry practices, the local informants considered that 27 species

391

392

393

394

395

396

397

398

399

400

401

402

403

404

405

406

407

408

409

410

411

412

413

414

415 were planted and/or grown naturally mainly for the use of live fences, shade for young coffee plantations, and economic purposes (Table S3). Likewise, the local informants thought that legume tree species and some other species were grown intentionally and sparsely in and around the cropland to increase soil fertility as a compost when falling leaves decompose into the soil and through nitrogen fixation via roots. These were Vachellia abyssinica, Erythrina brucei, Hagenia abyssinica, Sesbania sesban, Myrica salcifolia, Hypericum revolutum, Albizia schimperiana, Millettia ferruginea, Grevillea robusta, Vachellia seyal, and Vernonia amygdalina.

Fourteen plant species were used as local medicine in the district to treat various types of illnesses and pains. The most common species recorded in traditional medicines were Hagenia abyssinica, Ocimum lamiifolium, Eucalyptus globulus, Agarista salicifolia, Echinops longisetus, Hypericum revolutum, Myrsine africana, Millettia ferruginea, Croton macrostachyus, Buddleja polystachya, Ricinus communis, Vernonia amygdalina, Allium sativum, and Capsicum sp. Some of them were reported for wild edible species such as Carissa spinarum, Ficus sur, Ficus vasta, Osyris quadripartita, Rubus apetalus, Rosa abyssinica, Syzygium gineense subsp. afromontanum, Syzygium guineense subsp. guineense, Rumex nervosus, and Cordia africana. Thus, local planting efforts should focus on multipurpose species using a wide range of functions such as ecological suitability, climate mitigation, and economic and socio-cultural preferences of the local community. In the district, multipurpose plant species were ranked resulting in use categories of the direct matrix, with the highest scores obtained for Cordia africana and Hagenia abyssinica, as well as Croton macrostychus, Ficus sur, Ficus vasta, Syzygium guineense subsp. guineense, and Carrissa spinarum. A similar result was reported for C. africana in northern Ethiopia (Reubens et al., 2011).

All informants responded that crops are widely grown in both agricultural lands and homegardens, followed by plantation of agroforestry trees (97\%) (Table S4). Except for Kibate 
416 Forest, the natural forest patches are very limited cover in the form of sacred forest in churches

417 and riparian vegetation along the rivers, as well as in some peripheral areas of the farmlands,

418 which are owned by private persons and communities linked to governmental bodies. The third

419 frequently $(82 \%)$ reported natural resource in the study area was wetlands and shrubs. Shrubland

420 is found in several places, but they are small whereas wetlands are restricted into four sites.

421 Regarding water bodies, the largest lake (Harro Wonchi Crater Lake) and other small-sized water

422 bodies, and Walga and Amagna riparian vegetation were cited by $71 \%$ of the informants.

423 Additionally, small rivers at five sites have contributed to producing some crop trees and small

424 patches of riparian vegetation.

425 To sustain livelihoods and healthy ecosystem services and contribute to the food security and

426 nutritional needs of hundreds of millions of people worldwide in the face of climate variability

427 and change, a tree-based agricultural system is an important component (Moges, Eshetu \& Nune,

428 2010; IFC, 2011; Smith et al., 2012). In the presence of food shortages and increased threats of

429 climate change, agroforestry practice is critical to address both global and local challenges (EPA

430 1999; FAO 2004; Mbow et al., 2014). According to Smith et al. (2012), agroforestry practices

431 have the potential to sequester GHG globally ranges from 1500 to $4300 \mathrm{Mg} \mathrm{CO}_{2}$ equivalent per

432 year, with about $70 \%$ from developing countries; $90 \%$ of this potential found is in soil carbon

433 restoration and avoided net soil carbon emission. All, except six informants, reported that they

434 have practiced agroforestry management practices such as contour plowing, tracing of a sloped

435 area exposed to heavy erosion with grass species, and rehabilitating the vegetation with

436 multipurpose plant species. Reducing emissions from deforestation and forest degradation with

437 another benefit mechanism (i.e., REDD+) is supposed to address the reversal of forest-based land

438 degradation, conservation of existing carbon stocks, and enhancement of carbon sequestration

439 (Asfaw and Lemenih, 2010; Getu et al., 2011; Moges and Tenkir, 2014; Gizachew et al., 2017;

440 Meragiaw et al., 2021b). Wonchi District is predominantly agrarian with the potential for climate

441 change mitigation. Results indicated that most informants (94\%) understood the value of

442 REDD+ and smallholder farmers were willing to practice it when some necessary facilities were

443 fulfilled. Thus, the agroforestry practices should promote the practice of REDD+ among

444 smallholder farmers through education, motivation, seedling propagation, and incentive potential

445 to sustain interest in the strategy (Appiah et al., 2016). 
Very few numbers of informants (6\%) reported the positive effects of land-use changes on

447 the natural plant resources where croplands have been left to shrub covers and patches of the natural forest through time. Besides, crop rotation was mainly applied between cereal and legume crops as well as rotation between Solanum tuberosum and Hordeum vulgare was common practice in the study area as reported by many informants. Additionally, intercropping systems, and shifting cultivation/leaving improved fallow from 1 to 3 years to restore essential soil nutrients depend on the fertility of croplands. Shifting agriculture from crop farming to agroforestry has been practiced by small farmers in different parts of Africa including Ethiopia since time immemorial (Feoli, Vuerich \& Woldu, 2002; Meles, 2008; Smith et al., 2012; Luedeling et al., 2014; Mbow et al., 2014; Meragiaw, 2017; Meles et al., 2019). An increasing trend of agroforestry cover in Wonchi District (Fig. 3) is essentially the smart approach to responding to climate change and provides several integrated ecological services, environmental, and cultural, and socio-economic benefits.

In some sites of our study, it was difficult to delineate the agro-ecological zones because of the complex interaction of biotic and abiotic factors, as well as overlapping of agroforestry practices as described by Reubens et al. (2011), but larger numbers of multipurpose and crop species (63) were reported from the midland agro-ecological zone of the present study. This finding agreed with that Fikir, Tebikew \& Gebremariam (2018), who reported that plant species richness per household increased with the decreased agro-ecological gradient in northern Ethiopia. The species-specific occurrence could be due to the slight variation of altitude, edaphic conditions, and microclimatic and topographic characteristics (Meragiaw et al., 2018). The present study found that homegardens harbor highly taxonomically diverse agroforestry species (84) compared to other habitats, of which 17 species were only reported in homegardens (Table S4). This indicates that well-managed homegarden agroforestry systems give opportunities to grow multipurpose native trees over the environmentally unfriendly exotic tree species. However, more recently homegarden agroforestry has been challenged by population pressure, with the shift toward monoculture production of khat (Catha edulis) and Eucalyptus species as a new market situation in southern Ethiopia (Gebrehiwot, 2013). Furthermore, encroachments of the vegetation by the local people such as livestock overgrazing, burning of Erica Forest for expansion of agriculture, selective cutting tree species for charcoal, fencing, construction, and 
Humans have continually reshaped the Earth (Nair, 2007; Arevalo et al. 2011). Changes in LULC affect global systems (FAO, 2005; IPCC, 2003; Moges, Eshetu \& Nune, 2010; resources based on the results of Landsat data analysis could provide useful information to improve the financial incomes of communities, managers, and owners (Metzger et al., 2006; FAO 2012; FC 2011; Sabogal et al. 2013; Wulder et al., 2016), improve livelihoods ensuring food security, and environmental integrity (Torres-rojo and Flores-xolocotzi, 2001; FAO, 2012) and help in adapting to the changing climate $(F C, 2011)$. The Ethiopian land-use statistics indicate that woody vegetation including shrub and forest covers 50\% (61.6 million ha) of the land (WBISPP 2005; FAO 2006; Moges, Eshetu, Nune, 2010). However, the major sources of GHG emissions of the country are related to the use of biomass products and conversion of forest to monoculture production (Tefera et al., 2002; Gessesse, 2010). One of the recommendations for effective carbon management is that local stakeholders participate in planning and management decisions (Pearson, Walker \& Brown, 2005; Rizvi et al. 2015). Participation of local communities in decision making and benefit-sharing of open access forests could promote sustainable forest management (Torres-rojo and Flores-xolocotzi 2001).

\section{Implication for the protection and conservation of multipurpose species across the two} agro-ecological zones

Identifying areas with high endemism is important for conservation actions. In Wonchi District, the agroforestry system, riparian vegetation, and small patches of forest serve as a home for a considerable number of endemic plant species, wild animals, and many bird species. Meragiaw et al. (2018) and Meragiaw et al. (2021a) have recorded 10\% and 14\% of endemic species in Walga riparian vegetation and Kibate Forest of Wonchi District, respectively. In line with these studies, of the total number of species of the present study, about $7 \%$ of species were endemic to the flora area. These were Echinops longisetus, Erythrina brucei, Inula confertiflora, Maytenus arbutifolia, Millettia ferruginea, Rhus glutinosa subsp. neoglutinosa, and Solanecio gigas. Thus, serious attention needs to be given to the study area that is rich in multipurpose and endemic species. Sixty-six informants reported that local varieties of crops such as Vicia faba, Pisum sativum, Lens culinaris, and Sorghum bicolor showed variations in their distribution and yield over the last 34 years (Table S4). They speculate the continuous use of chemical fertilizers (Urea 
507 and DAP) and herbicides for cereal crops may have led to the reduction of their yields. Thus,

508 farmers replaced those crops with other crop species that give better yields in response to the use 509 of agrochemicals. Similarly, Plectranthus edulis is nearly extinct in the district due to the 510 reduction of marshy areas which favor its growth. Conversely, Solanum tuberosum, Zea mays, 511 and many crop trees have been introduced in recent times and are grown in homegardens and 512 along the river edges in Wonchi District.

513 A combination study of agroforestry trees, forests, and land use provides baseline

514 information for climate change mitigation, biodiversity conservation, trends, and distribution of 515 land-use types $(F A O, 2019)$. The present study showed that agroforestry cover was found to be 516 the dominant type of classified land use that covers about $34.9 \%$ of the total study area, followed 517 by settlement and road construction (31.6\%) and croplands (24.8\%) in 2019 (Table S6). Similar 518 findings were reported elsewhere in global drylands (FAO 2019) and Limpopo province 519 (Rwanga \& Ndambuki, 2017). Thus, the increase was observed in agroforestry, and settlement 520 and built-up areas from 1985 to 2019 (Table 6 and Fig. 3). On the other hand, forest cover and 521 shrub cover followed a declining trend. The driving force behind a decline of woody vegetation 522 was infrastructure development such as a long-time ongoing ca. $40 \mathrm{~km}$ road construction from 523 Ambo to Woliso, climate change, and population growth. Research findings in northern Ethiopia

524 (Tegene, 2002; Dragan et al., 2003; Duguma et al., 2019) and in Islamabad, Pakistan (Hassan et 525 al., 2016) indicated that the rapid expansion of agriculture and deforestation resulted in a wide 526 range of environmental degradation and soil erosion. Thus, such environmental degradation 527 requires finding policy tools and mechanisms for appropriate land-use management where 528 stakeholders participate in the decision-making process. The present finding may deliver a proper 529 understanding of how the land was used in the past, how the land cover has changed over time, 530 and how to make assessments of the changes one could expect in the future and these changes 531 will have impacts on natural resources and peoples' lives as described by FAO (2005). A 532 sustainable increase in production might be achieved through the diversification of land use by 533 combining livestock grazing measures, physical soil conservation measures, and planting 534 multipurpose trees. Combining trees and crops in different arrangements has been shown to 535 improve food and nutritional security and mitigate environmental degradation, offering a 536 sustainable alternative to monoculture production (Nair, 2007; Asfaw and Lemenih, 2010; 537 Lemenih and Woldemariam, 2010; Meragiaw, 2017; Meles et al., 2019). 
538

539

540

541

542

543

544

545

546

547

548

549

550

551

552

553

554

555

556

557

558

559

560

561

562

563

564

565

566

567

568

Furthermore, some of the possible solutions to restore and conserve the remaining natural forests were suggested by informants, including plantation of indigenous multipurpose and crop tree species, strengthening of shifting cultivation, creating awareness, and serious management practices that could be enforced by the concerned governmental bodies. The initiative of planting some agroforestry multipurpose species in collaboration between the 'Seleme Project' and Wonchi District Agricultural and Rural Development Office for conservation and management purposes should be encouraged. Plant species growing in the nursery site of the Miti Walga include Dendrocalamus asper, Dendrocalamus barbatus, Bambusa polymorpha, Sesbania sesban, Juniperus procera, Hagenia abyssinica, Olea europaea subsp. cuspidata, Arundinaria alpina, Cordia africana, Grevillea robusta, Vachellia abyssinica, and Jacaranda mimosifolia should be scaled up. The integration of conservation practices such as rehabilitation, and community-based management of natural resources need to be expanded to reduce major threats (Table S4). The development of other alternative sources of income for youths will resolve the dilemma between farmland expansion associated with rapid population growth and forest conservation projects. Many researchers agreed that the traditional agroforestry system based on the preferences of local stakeholders has great benefits (FAO, 2011a; FAO, 2011b; Reubens et al., 2011). In many African countries, increases in crop production came more from area expansion rather than from productivity increases. Available data show that in Africa and particularly in Ethiopia, there is limited potential for further area expansion (Binswanger \& Pingali, 1988). Thus, an alternative farming system that yields much higher crop production could be more sustainable and environmentally friendly. Agroforestry has been demonstrated to be a viable option to balance biodiversity conservation and crop production depending on wise management decisions in the agricultural sector.

\section{Conclusions}

The present study assessed the historical LULC changes and the potential of traditional agroforestry practices as strategic elements in land-use planning and mitigation to climate change in Wonchi District. The study area is taxonomically diverse with a total of 103 agroforestry plant species were distributed in 44 families including 41 crop and 62 multipurpose species. Of which 74 indigenous including seven endemic and 29 exotic species were documented. A mixed farming system was the most frequently (56\%) reported source of income in both agroecological zones. The results of LULC changes from 1985 to 2019 showed that the total area of 
569 agroforestry cover and settlement including road construction increased with an annual rate 570 change of $0.3 \%$ and $2.7 \%$, respectively. These changes corresponded with a conversion of forest 571 cover, which decreased at a rate of $4.7 \%$ at a larger scale than other land-use types. Agroforestry 572 activities, expansion of settlement and road construction, and tenure policy change exacerbated

573 by increased human population numbers are the main drivers to the area. The LULC changes 574 were more observable in the highlands of Wonchi District. However, the findings on activities of 575 agroforestry systems and LULC changes could provide insights for achieving multiple goals of

576 biodiversity conservation, poverty reduction, and land-use planning for sustainable development 577 and climate change adaptation and mitigation in the region. Hence, the findings of the present 578 study may provide an input for the 2030 plan of the Ethiopian government that target to (1) 579 improve crop and livestock production practices for greater food security and higher farmer 580 incomes while reducing emissions; and (2) protect and re-establish forests for their economic and

581

582

583

584

585

586

587

588

589

590

591

592

593

594

595

596 ecosystem services, while sequestering significant amounts of $\mathrm{CO}_{2}$ and increasing the carbon stocks in landscapes. The authors recommended that every bit of the available land should be used most rationally based on the LULC data that provides to improve the natural resources of the area without further deteriorating the bio-environment. Thus, more research and effort are needed to address the full potential of traditional agroforestry practices and realize the modern land-use systems with a more sustainable and all-inclusive approach to land management.

\section{Acknowledgements}

The Department of Plant Biology and Biodiversity is gratefully acknowledged for facilitating a short-term GIS and remote sensing training and supporting research project. We are also grateful to Dr. Elliott Pearl for English language proofreading. Finally, we would like to thank Mr. Yesuf Dawud, the field driver, and the people of Wonchi District, and the field guides for providing relevant field information.

\section{References}

Albrecht A, Kandji ST. 2003. Carbon sequestration in tropical agroforestry systems. Ecosystems and Environment 99:15-27. DOI 10.1016/S0167-8809(03)00138-5.

Ali HO, Descheemaeker K, Steenhuis TS, Pandey S. 2011. Land Use and Land Cover Changes 
597

598

599

600

601

602

603

604

605

606

607

608

609

610

611

612

613

614

615

616

617

618

619

620

621

622

623

624

625

626

in the Ethiopian Highlands. Cornell-Bahir Dar University, Ethiopia.

Appiah DO, Bugri JT, Forkuo EK, Yamba S. Agricultural and Forest Land Use Potential for REDD+ among Smallholder Land Users in Rural Ghana. International Journal of Forestry Research 2016: 7218305 DOI 10.1155/2016/7218305.

Arevalo CBM, Bhatti JS, Chang SX, Sidders D. 2011. Land-use change effects on ecosystem carbon balance : From agricultural to hybrid poplar plantation. Agriculture, Ecosystems and Environment 141:342-349. DOI 10.1016/j.agee.2011.03.013.

Asfaw B, Lemenih M. 2010. Traditional Agroforestry Systems as a Safe Haven for Woody Plant Species: A Case Study from a Topo-Climatic Gradient in South Central Ethiopia. Forests, Trees and Livelihoods 19: 359-377. DOI 10.1080/14728028.2010.9752678Corpus.

Bălteanu D, Dragotă C-S, Popovici AM, Dumitraşcu A, Kucsicsa G, Grigorescu I. 2013. Land use and crop dynamics related to climate change signals. Proc. Rom. Acad., Series 15 (3):265-78.

Birhanu, L., Hailu, B.T., Bekele, T., Demissew, S. (2019). Land use/cover change along elevation and slope gradient in highlands of Ethiopia. Remote Sensing Applications: Society and Environment 16:100260. DOI 10.1016/j.rsase.2019.100260.

Brown DG, Polsky C, Bolstad P, Brody SD, Hulse D, Kroh R, Loveland TR, Thomson A. 2014. Ch. 13: Land Use and Land Cover Change. In Climate Change Impacts in the United States: The Third National Climate Assessment, Melillo JM, Richmond TTC, Yohe GW (Eds.). U.S. Global Change Research Program 318-332.

Congalton R. 1991. A review of assessing the accuracy of classifications of remotely sensed data. Remote Sens. Environ. 37:35-46. DOI 10.1016/0034-4257.

Cotton CM. 1996. Ethnobotany: Principles and Application. John Wiley \&Sons Ltd., New York. CSA. 2008. Central Statistical Agency: Livelihood profile. Oromia Region, Ethiopia.

Cunningham AB. 2001. Applied Ethnobotany: People, Wild Plant Use and Conservation. Earthscan.

Dragan M, Feoli E, Fernetti M, Woldu Z. 2003. Application of a spatial decision support system (SDSS) to reduce soil erosion in northern Ethiopia. Environmental Modelling \& Software 18:861-868. DOI 10.1016/S1364-8152(03)00104-X. 
627 Duguma LA, Atela J, Minang PA, Ayana AN, Gizachew B, Nzyoka JM, Bernard F. 2019.

628 Deforestation and forest degradation as an environmental behavior: Unpacking realities 629 shaping community actions. Land 8: 26. DOI 10.3390/land8020026.

630 EPA. 1999. Land Cover Trends: Rates, Causes, and Consequences of Late-Twentieth Century 631 Edited by T.R. Loveland. Washington, D.C.: U.S. Environmental Protection Agency. 632 FAO. 2004. Assessing carbon stocks and modeling win-win scenarios of carbon sequestration 633 through land-use changes. FAO, Rome, Italy.

634 FAO. 2005. Land Cover Classification System Classification Concepts and User Manual.

635 Environment and Natural Resources Service (SDRN) publications, Rome, Italy.

636 Available on: $\underline{\text { www.fao.org/sd/enpub1_en.htm. }}$

637 FAO. 2006. Global Forest Resource Assessment 2005: Progress towards Sustainable

638 Forest Management. FAO, Rome, Italy.

639 FAO. 2011a. Tees outside Forests: Towards Rural and Urban Integrated Resources

640 Management. Rome, Italy.

641 FAO. 2011b. State of the World's Forests. FAO, Rome, Italy.

642 FAO. 2012. Forests and Climate Change Working Paper 10: Forest Management and Climate 643 Change: A Literature Review. FAO/UN, Rome, Italy.

644 FAO. 2019. Trees, forests, and land use in drylands: the first global assessment -Full report. $645 \quad$ FAO Forestry Paper No. 184. Rome, Italy.

646 FC. 2011. Forests and Climate Change: UK Forestry Standard Guidelines. Edinburgh: First 647 published by the Forestry Commission. www.nwww.forestry.gov.uk/publications.

648 Feoli E, Vuerich LG, Woldu Z. 2002. Processes of environmental degradation and opportunities 649 for rehabilitation in Adwa, northern Ethiopia. Landscape Ecol. 17:315-325. DOI $650 \quad 10.1023 / \mathrm{A}: 1020566801067$.

651 Fikir D, Tebikew M, Gebremariam Y. 2018. Diversity of Indigenous Woody Species in Small 652 Holder Farm Lands: Comparison across Different Agroecology and Land Use Types in 653 Chilga and Dabat District, Northern Ethiopia. International Journal of Scientific 654 Research and Management 6(08): AH-2018-178-189, DOI 10.18535/ijsrm/v6i8.ah01. 655 Friis I, Demissew S, Breugel VP. 2010. Atlas of the potential vegetation of Ethiopia. 656 Copenhagen. Biol. Skr. 58. 
657 Gebrehiwot M. 2013. Recent Transitions in Ethiopian Homegarden Agroforestry: Driving Forces

658

659

660

661

662

663

664

665

666

667

668

669

670

671

672

673

674

675

676

677

678

679

680

681

682

683

684

685

686 and Changing Gender Relations. Licentiate Thesis Swedish University of Agricultural Sciences Umeå 2013. Acta Universitatis Agriculturae Sueciae 2013:21.

Gedefaw M, Soromessa M, Belliethathan S. 2014. Forest carbon stocks in woody plants of Tara Gedam Forest: Implication for climate change mitigation. Sci. Technol. Arts Res. J. 3(1): 101-107. DOI 10.4314/star.v3i1.16.

Gessesse B. 2010. Review of Land Degradation and Land Management in Ethiopia up to 2008/09. In: Forum for Environment. Ethiopian Environment Review, No. 1. Addis Ababa, Ethiopia.

Getu Z, Dale G, Tafa M, James GN, Gonfa T. 2011. Carbon Stock Assessment in Different Land Use for REDD+ in Ethiopia: Practitioners Field Guide, Yayu forest coffee biosphere reserve. Addis Ababa, Ethiopia.

Gizachew B, Astrup R, Vedeld P, Zahabu EM, Duguma LA. 2017. REDD+ in Africa: contexts and challenges. Natural Resources Forum DOI: 10.1111/1477-8947.12119.

Hassan Z, Shabbir R, Ahmad SS, Malik AH, Aziz N, Butt A, Erum S. 2016. Dynamics of land use and land cover change (LULCC) using geospatial techniques: a case study of Islamabad Pakistan. SpringerPlus 5: 812. DOI 10.1186/s40064-016-2414-Z.

Helen, Jarzebski MP, Gasparatos A. 2019. Land-use change, carbon stocks, and tree species diversity in green spaces of a secondary city in Myanmar, Pyin Oo Lwin. PLoS ONE 14(11): e0225331. DOI 10.1371/journal.pone.0225331.

IFC (2011). Guidance Note 6-V2 Biodiversity Conservation and Sustainable Management of Living Natural Resources. International Finance Corporation, World Bank Group. IPCC. 2003. Good Practice Guidance for Land Use, Land-Use Change, and Forestry, Prepared by the National Greenhouse Gas Inventories Programme, [Penman J, Gystarsky M, Hiraishi T, Krug T, Kruger D, Pipatti R, Buendia L, Miwa K, Ngara T, Tanabe K, Wagner F. (Eds.)]. IGES, Japan.

Kyalangalilwa B, Boatwright JS, Daru BH, Maurin O, van der Bank M. 2013. Phylogenetic position and revised classification of Acacia s.l. (Fabaceae: Mimosoideae) in Africa, including new combinations in Vachellia and Senegalia. Botanical Journal of the Linnean Society 172(4): 500-523. DOI 10.1111/boj.12047.

PeerJ reviewing PDF | (2021:10:66775:1:1:NEW 4 Jan 2022) 
687 Lemenih M. 2006. Expediting ecological restoration with the help of foster tree plantations in 688 Ethiopia. Journal of the Drylands 1(1): 72-84

689 Lemenih M, Woldemariam T. 2010. Review of Forest, Woodland and Bushland Resources in 690 Ethiopia up to 2008: In Forum for Environment. Ethiopian Environment Review, No.1, 691 2010, Addis Ababa, Ethiopia.

692 Luedeling E, Kindt R, Huth N, Koenig K. 2014. Agroforestry systems in a changing climate693 challenges in projecting future performance. Current Opinion in Environmental 694 Sustainability 6:1-7. DOI 10.1016/j.cosust.2013.07.013.

695 Mahoo H, Radeny M, Kinyangi J, Cramer L. (Eds). 2013. Climate change vulnerability and risk 696 assessment of agriculture and food security in Ethiopia: Which way forward? CCAFS 697 698 699 700 701 702

Mbow C, Smith P, Skole D, Duguma1L, Bustamante M. 2014. Achieving mitigation and adaptation to climate change through sustainable agroforestry practices in Africa. In: Sustainability challenges Mbow C, Neufeldt H, Minang PA, Luedeling E, Kowero G. (Eds.). Current Opinion in Environmental Sustainability 6:8-14.

Meles K, Bishaw B, Iiyama M, Emiru B, Negussie N, Davis CM, Bernart B. (Eds). 2019. Climate-Smart Agriculture: Enhancing Resilient Agricultural Systems, Landscapes, and Livelihoods in Ethiopia and Beyond. World Agroforestry (ICRAF), Nairobi, Kenya.

Meles K. 2008. Temporal and Spatial Changes in Land Use Patterns and Biodiversity in Relation to Farm Productivity at Multiple Scales in Tigray, Ethiopia. PhD Thesis Wageningen University, Wageningen, The Netherlands.

Menker H, Hassan RM. 2011. Drivers of land-use change in the Southern Nations, Nationalities and People's Region of Ethiopia. Afr. J. Agr. Res. Econ. 9 (2):148-164. DOI 10.22004/ag.econ.176515. 
716 Meragiaw M, Woldu Z, Martinsen V, Singh BR. 2018. Woody species composition and diversity

717

718

719

720

721

722

723

724

725

726

727

728

729

730

731

732

733

734

735

736

737

738

739

740

741

742

743

744

745

746

of riparian vegetation along the Walga River, Southwestern Ethiopia. PLoS ONE 13(10): e0204733 DOI 10.1371/journal.pone.0204733.

Meragiaw M, Woldu Z, Martinsen V, Singh BR. 2021a. Floristic composition and structure of the Kibate Forest along environmental gradients in Wonchi, Southwestern Ethiopia. $J$. For. Res. 32: 2669-2682 (2021). DOI 10.1007/s11676-021-01305-Z

Meragiaw M, Woldu Z, Martinsen V, Singh BR. 2021b. Carbon stocks of above- and belowground tree biomass in Kibate Forest around Wonchi Crater Lake, Central Highland of Ethiopia. PloS ONE 16(7): e0254231. DOI 10.1371/journal.pone.0254231.

Meragiaw M. 2017. Role of agroforestry and plantation on climate change mitigation and carbon sequestration in Ethiopia. Journal of Tree Sciences 36(1): 1-15 DOI 10.5958/24557129.2017.00001.2.

Metzger MJ, Rounsevell MDA, Acosta-michlik DS, Leemans LR. 2006. The vulnerability of ecosystem services to land-use change. Agriculture, Ecosystems and Environment 114:69-85. DOI 10.1016/j.agee.2005.11.025.

MOA. 2000. Agro-ecological zones of Ethiopia. Ministry of Agriculture, Addis Ababa: Natural Resource Management and Regulatory Department.

Moges Y, Eshetu Z, Nune S. 2010. Ethiopian Forest Resources: Current Status and Future Management Options in View of Access to Carbon Finances. Forestry Research Center, EIAR/NBCU Project Office in Ethiopia, Addis Ababa, Ethiopia.

Moges Y, Tenkir E. 2014. Overview of REDD+ Process in Ethiopia. Ministry of Environment and Forest, Addis Ababa, Ethiopia.

Nair PKR. 2007. Perspective: The coming of age of agroforestry. J Sci Food Agric. 00225142/2007 DOI 10.1002/jsfa.2897.

NCDC. 2013. Historical Land-Cover Change and Land Use Conversions Global Dataset. National Climatic Data Center 151 Patton Ave. Asheville, USA.

Pareta K, Pareta U. 2011. Forest carbon management using satellite remote sensing techniques a case study of Sagar district (MP). E-International Scientific Research Journal 3 (4) 33548.

Pearson TRH, Walker S, Brown SL. 2005. Source Book for LULUCF Projects. Winrock International, Arlington, VA, USA.

Peer) reviewing PDF | (2021:10:66775:1:1:NEW 4 Jan 2022) 
747 Pelton JN, Madry S, Camacho-Lara S. (Eds). 2013. Handbook of Satellite Applications. Springer 748 Science+Business Media DOI 10.1007/-978-1-4419-7671-0.

749 Puyravaud JP. 2003. Standardizing the calculation of the annual rate of deforestation. For. Ecol.

750

751

752

753

754

755

756

757

758

759

760

761

762

763

764

765

766

767

768

769

770

771

772

773

774

775

776 Manag. 177 (2003):593-596 DOI 10.1016/S0378-1127(02)00335-3.

Rawat JS, Kumar M. 2015. Monitoring land use/cover change using remote sensing and GIS techniques: A case study of Hawalbagh block, district Almora. Uttarakhand, India.

Reubens B, Moeremans C, Poesen J, Nyssen J, Tewoldeberhan S, Franzel S, Deckers J, Orwa C, Muys B. 2011. Tree species selection for land rehabilitation in Ethiopia: from fragmented knowledge to an integrated multi-criteria decision approach. Agroforest Syst. 82:303-330 DOI 10.1007/s10457-011-9381-8.

Rizvi AR, Baig S, Barrow E, Kumar C. 2015. Synergies between Climate Mitigation and Adaptation in Forest Landscape Restoration. Gland, Switzerland: IUCN.

Rwanga SS, Ndambuki JM. 2017. Accuracy assessment of land use/cover classification using remote sensing and GIS. International Journal of Geosciences 8:611-622. DOI 10.4236/ijg.2017.84033.

Sabogal C, Guariguata MR, Broadhead J, Lescuyer G, Savilaakso S, Essoungou N, Sist P. 2013. Multiple-use Forest management in the humid tropics: opportunities and challenges for sustainable forest management. FAO Forestry Paper No. 173. Rome, FAO/UN, and Bogor, Indonesia, Center for International Forestry Research.

Saputra MH, Lee HS. 2019. Prediction of land use and land cover changes for North Sumatra, Indonesia, using an artificial-neural-network-based cellular automaton. Sustainability 11: 3024. DOI 10.3390/su11113024.

SD21 (Sustainable development in the $21^{\text {st }}$ century). 2012. Sustainable Land Use for the $21^{\text {st }}$ Century. United Nations, Department of Economic and Social Affairs, USA.

Smith P, Wollenberg E. 2012. Achieving mitigation through synergies with adaptation. In Climate Change Mitigation and Agriculture. Edited by Wollenberg E, Nihart A, TapioBostro"m M-L, Grieg-Gran M. London-New York: ICRAF-CIAT. Pp.50-57.

Tefera B, Ayele G, Atnafe Y, Jabbar MA, Dubale P. 2002. Nature and causes of land degradation in the Oromiya Region. Socio-economic and Policy Research Working Paper 36. ILRI, Nairobi, Kenya. 
777 Tegene B. 2002. Land-cover/land-use changes in the Derekolli catchment of the South Welo

778

779

780

781

782

783

784

785

786

787

788

789

790

791

792

793

794

795

796

797

798

799

800

801

802

803
Zone of Amhara Region, Ethiopia. Eastern Africa Social Science Research Review 18 (1):1-20.

Torres-rojo JM, Flores-xolocotzi R. 2001. Deforestation and land-use change in Mexico. Climate Change and Forest Management in the Western Hemisphere 12 (1):171-91.

Tumwebaze BS. (2012). Impact of land use/cover change on soil carbon stocks, livelihoods, and opportunities for mitigation in Mt. Elgon region. Research Application Summary, Third Ruforum Biennial Meeting 24-28 September 2012, Entebbe, Uganda.

Venter O, Sanderson EW, Magrach A, Allan JR, Beher J, Jones KR, Possingham HP, Laurance WF, Wood P, Fekete BM, Levy MA, Watson JEM. 2016. Sixteen years of change in the global terrestrial human footprint and implications for biodiversity conservation. Nat. Commun. 7:12558 DOI. 10.1038/ncomms 12558.

WBISPP. 2005. Woody Biomass Inventory and Strategic Planning Project. National strategy plan for the biomass sector. Addis Ababa, Ethiopia.

Weng Q. 2001. A remote sensing-GIS evaluation of urban expansion and its impact on surface temperature in the Zhujiang Delta, southern China. Inter. J. Rem. Sens. 22(10):999-2014.

Weng Q. 2010. Remote Sensing and GIS Integration, Theories, Methods, and Applications. McGraw-Hill, New York.

Wulder MA, White JC, Loveland TR, Woodcock CE, Belward AS, Cohen WB, Fosnight EA, Shaw J, Masek JG, Roy DP. 2016. The global Landsat archive: Status, consolidation, and direction. Remote Sensing of Environment 185:271-283. DOI. 10.1016/j.rse.2015.11.032.

Yahya N, Mulat S, Getachew M. 2019. Technical Manual on the Use of Satellite Images in Ecological Studies. Ethiopian Environment and Forest Research Institute, Addis Ababa, Ethiopia. Available on: http://www.eefri.org/

Zeledon EB, Kelly NM. 2009. Understanding large-scale deforestation in Southern Jinotega, Nicaragua from 1978 to 1999 through the examination of changes in land use and land cover. Journal of Environmental Management 90. DOI 10.1016/j.jenvman.2008.03.016. 
Figure 1

Map of Ethiopia showing the study area and selected sites in the two agro-ecological zones.

The shape file data for the location map of the study area in Figure 1 were obtained from the Ethiopian Mapping Agency ( https://africaopendata.org/dataset/ethiopia-shapefiles ), which is free and open to researchers. 


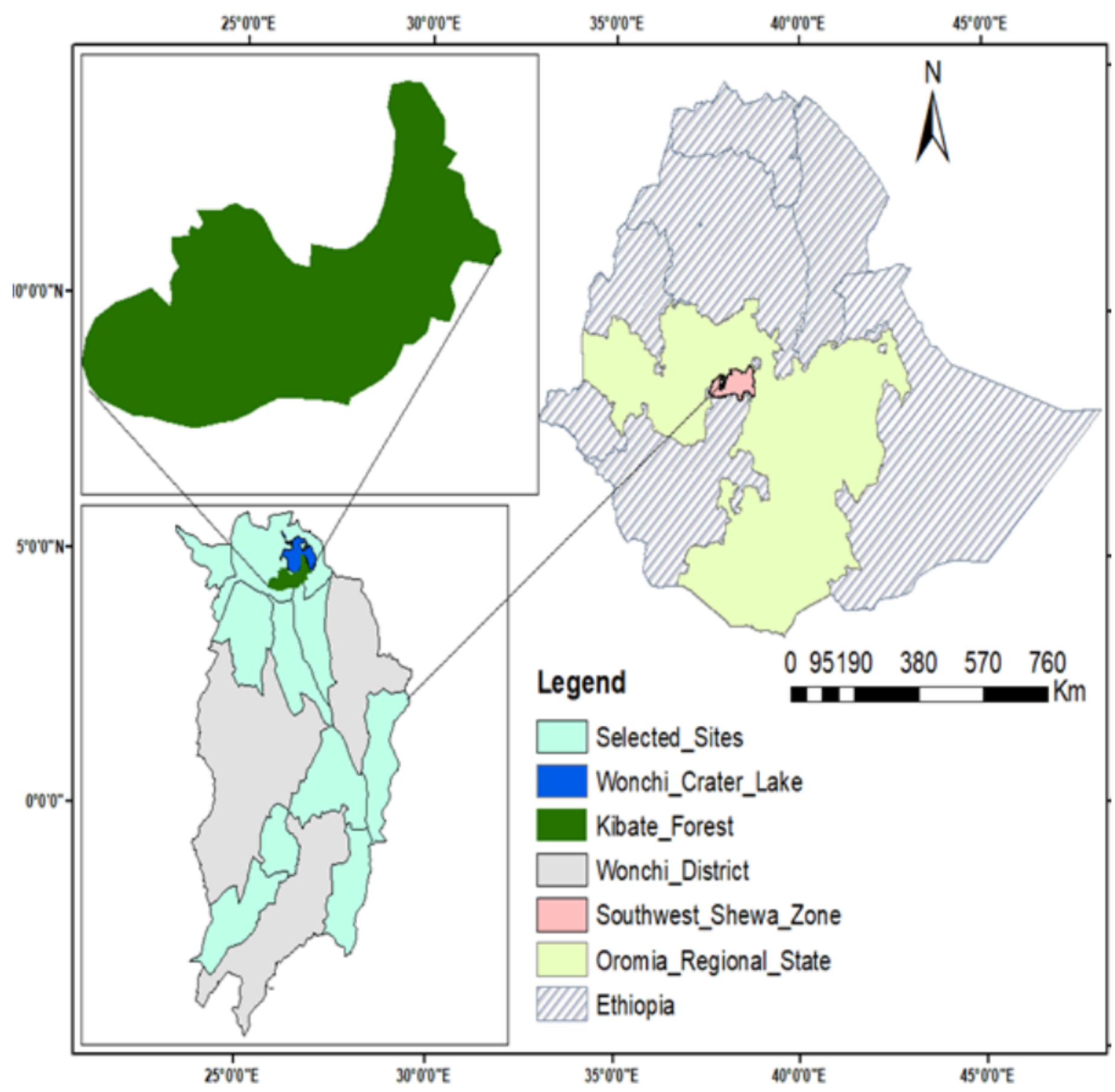


Figure 2

Satellite imageries of 1985, 2001, and 2019 with six LULC classes in Wonchi District.

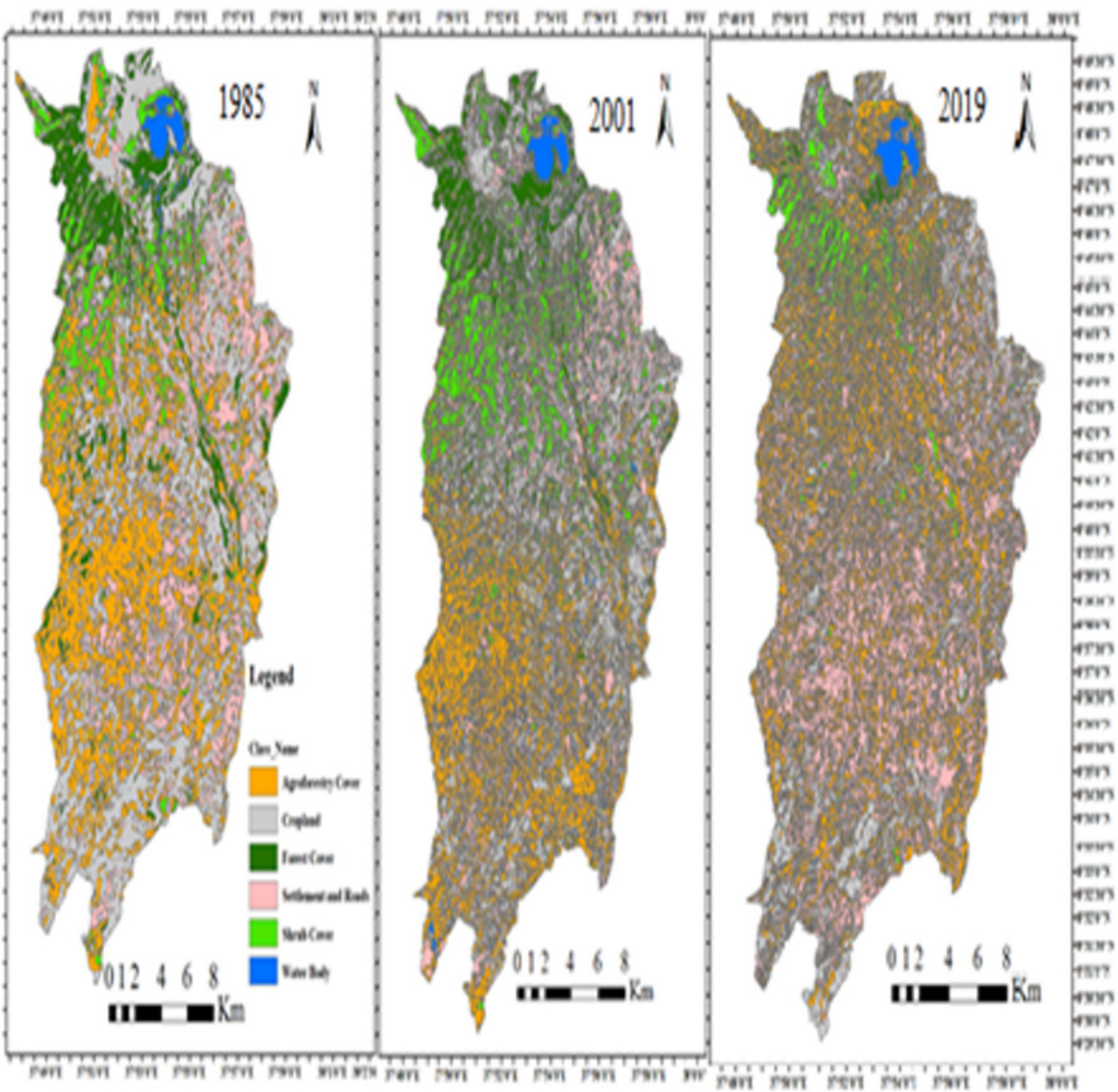


Figure 3

Total trends of LULC types of area change in percentage for six LULC classes in three time-series of the study area.

$A R C=$ Annual rate of change; the bar graphs above zero show positive values and suggest an increase, and those below zero indicate negative values and a decrease in the area of LULC type. 


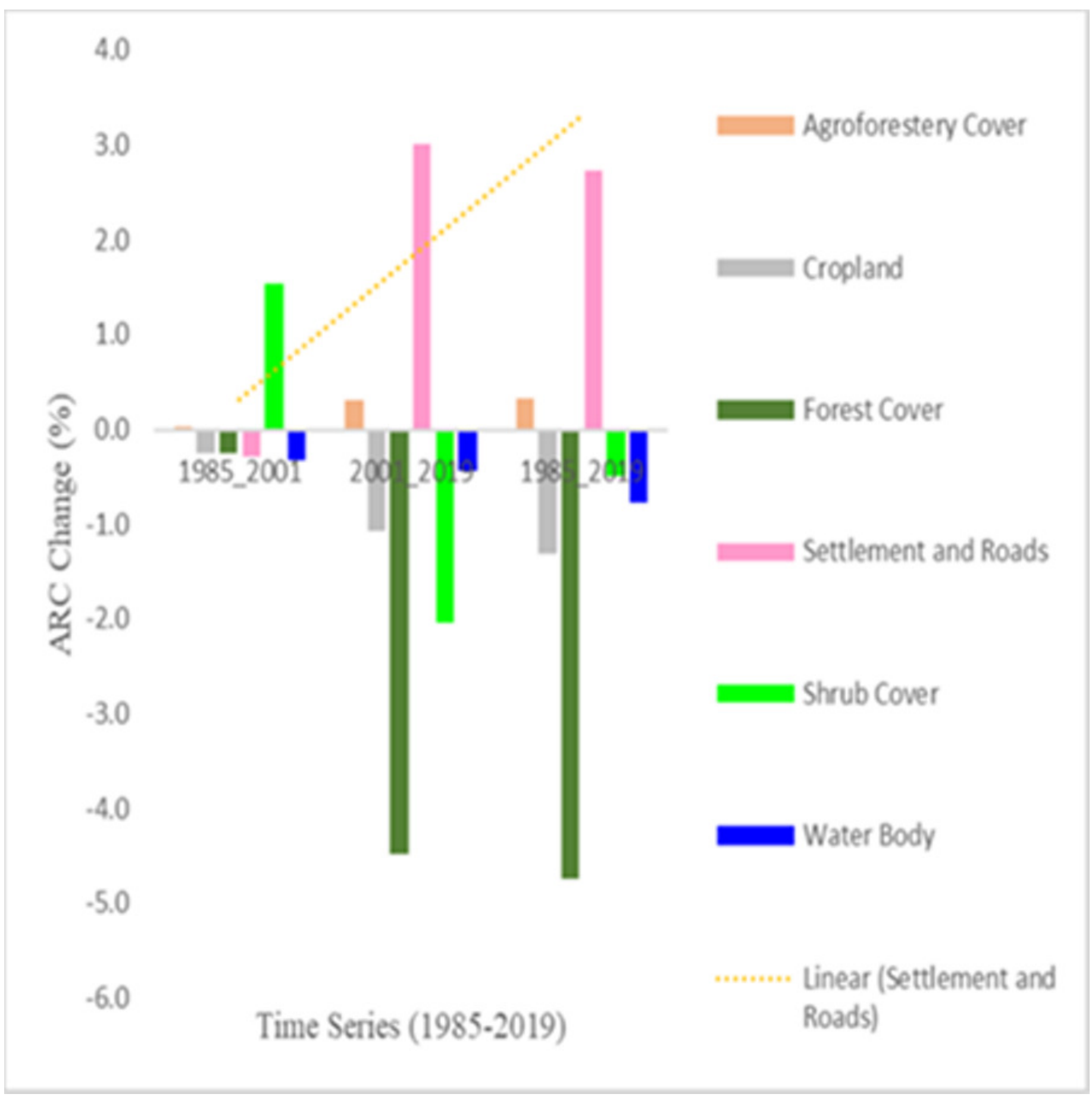




\section{Table $\mathbf{1}$ (on next page)}

Details of acquired satellite image in the study area.

$\mathrm{TM}=$ Thematic Mapper; $\mathrm{ETM}^{+}=$Enhanced Thematic Mapper $; \mathrm{OLI}=$ Operational Land Imager. 


\begin{tabular}{llrrrrr}
\hline $\begin{array}{l}\text { Landsat } \\
\text { Type \&ID }\end{array}$ & Acquisition & \multicolumn{1}{l}{$\begin{array}{l}\text { Spatial } \\
\text { date }\end{array}$} & $\begin{array}{l}\text { Spectral } \\
\text { resolution }\end{array}$ & Path /raw & Sensor & Sun Elevation \\
\hline Landsat 5 & $09-11-1985$ & $30 \mathrm{~m}$ & 7 & $169 / 054$ & TM & 51.21971477 \\
Landsat 7 & $28-10-2001$ & $30 \mathrm{~m}$ & 7 & $169 / 054$ & ETM+ & 57.23935453 \\
Landsat 8 & $07-01-2019$ & $30 \mathrm{~m}$ & 11 & $169 / 054$ & OLI & 49.07093407 \\
\hline
\end{tabular}

1 


\section{Table 2 (on next page)}

Crop diversity in the two agro-ecological zones of Wonchi District.

a stands for species that are reported only in the midland agro-ecological zone. 


\begin{tabular}{|c|c|c|c|c|c|}
\hline $\begin{array}{l}\text { Oilseed, cereal, an } \\
\text { crops }\end{array}$ & id legume & Vegetables and sp & ices & Tree crops & \\
\hline Species & Family & Species & Family & Species & Family \\
\hline $\begin{array}{l}\text { Hordeum vulgare } \\
\text { L. }\end{array}$ & Poaceae & $\begin{array}{l}\text { Capsicum } \\
\text { annuum } \mathrm{L} .\end{array}$ & $\begin{array}{l}\text { Solanacea } \\
e\end{array}$ & $\begin{array}{l}\text { Malus domestica } \\
\text { Borkh }\end{array}$ & Rosaceae \\
\hline $\begin{array}{l}\text { Ensete ventricosum } \\
\text { (Welw.) Cheesman }\end{array}$ & Musaceae & $\begin{array}{l}\text { Solanum } \\
\text { tuberosum L. }\end{array}$ & $\begin{array}{l}\text { Solanacea } \\
e\end{array}$ & Morus alba L. & Moraceae \\
\hline $\begin{array}{l}\text { Triticum durum } \\
\text { Desf. }\end{array}$ & Poaceae & $\begin{array}{l}\text { Brassica carinata } \\
\text { A. Br. }\end{array}$ & $\begin{array}{l}\text { Brassicac } \\
\text { eae }\end{array}$ & Prunus persica $L$. & Rosaceae \\
\hline $\begin{array}{l}\text { Triticum aestivum } \\
\text { L. }\end{array}$ & Poaceae & Allium cepa L. & Alliaceae & $\begin{array}{l}\text { Catha edulis }{ }^{\mathrm{a}} \\
\text { (Vahl) } \\
\text { Endl. }\end{array}$ & $\begin{array}{l}\text { Celastracea } \\
\mathrm{e}\end{array}$ \\
\hline Vicia faba $\mathrm{L}$. & Fabaceae & Allium sativum L. & Alliaceae & $\begin{array}{l}\text { Citrus limon }{ }^{\mathrm{a}} \quad \text { (L.) } \\
\text { Burm.f. }\end{array}$ & Rutaceae \\
\hline $\begin{array}{ll}\text { Lens } & \text { culinaris } \\
\text { Medikus }\end{array}$ & Fabaceae & Capsicum sp. & $\begin{array}{l}\text { Solanacea } \\
e\end{array}$ & Coffea arabica ${ }^{\mathrm{a}} \mathrm{L}$. & Rubiaceae \\
\hline Pisum sativum L. & Fabaceae & $\begin{array}{l}\text { Lycopersicon } \\
\text { esculentum Mill. }\end{array}$ & $\begin{array}{l}\text { Solanacea } \\
e\end{array}$ & $\begin{array}{l}\text { Citrus sinensis } \\
\text { (L.) Osb. }\end{array}$ & Rutaceae \\
\hline Cicer arietinum L. & Fabaceae & $\begin{array}{l}\text { Saccharum } \\
\text { officinarum }^{\text {a }} \text { L. }\end{array}$ & Poaceae & $\begin{array}{l}\text { Persea americana } \\
\text { Mill. }\end{array}$ & Lauraceae \\
\hline $\begin{array}{l}\text { Eragrostis } \quad \text { tef } \\
\text { (Zucc.) }\end{array}$ & Poaceae & $\begin{array}{l}\text { Beta vulgaris var. } \\
\text { esculenta }^{\mathrm{a}} \mathrm{L} \text {. }\end{array}$ & $\begin{array}{l}\text { Chenopod } \\
\text { iaceae }\end{array}$ & $\begin{array}{ll}\text { Musa } & x \\
\text { paradisiaca }^{\text {a }} \text { L. } & \end{array}$ & Musaceae \\
\hline $\begin{array}{l}\text { Linum } \\
\text { ustatissimum L. }\end{array}$ & Linaceae & Daucus carota L. & Apiaceae & $\begin{array}{l}\text { Mangifera indica } \\
\text { L. }\end{array}$ & $\begin{array}{l}\text { Anacardiac } \\
\text { eae }\end{array}$ \\
\hline Zea mays ${ }^{\mathrm{a}} \mathrm{L}$. & Poaceae & $\begin{array}{l}\text { Brassica } \\
\text { oleracea }^{\text {a }} \mathrm{L} .\end{array}$ & $\begin{array}{l}\text { Brassicac } \\
\text { eae }\end{array}$ & $\begin{array}{l}\text { Psidium guajava }^{a} \\
\text { L. }\end{array}$ & Myrtaceae \\
\hline $\begin{array}{l}\text { Sorghum } \text { bicolor }^{\mathrm{a}} \\
\text { L. }\end{array}$ & Poaceae & $\begin{array}{l}\text { Plectranthus } \\
\text { edulis }^{\mathrm{a}} \quad \text { (Vatke) } \\
\text { Agnew }\end{array}$ & $\begin{array}{l}\text { Lamiacea } \\
e\end{array}$ & $\begin{array}{l}\text { Casimiroa edulis } \\
\text { La Llave }\end{array}$ & Rutaceae \\
\hline Lathyrus sativus ${ }^{\mathrm{a}} \mathrm{L}$. & Fabaceae & $\begin{array}{l}\text { Cuminum } \\
\text { cyminum }^{\text {a }} \mathrm{L} .\end{array}$ & Apiaceae & $\begin{array}{l}\text { Rhamnus prinoides } \\
\text { L'Herit }\end{array}$ & $\begin{array}{l}\text { Rhamnacea } \\
\text { e }\end{array}$ \\
\hline $\begin{array}{l}\text { Guizotia } \\
\text { abyssinica }^{\text {a }} \quad \text { (L.f.) } \\
\text { Cass. }\end{array}$ & $\begin{array}{l}\text { Asteracea } \\
\text { e }\end{array}$ & & & Carica papaya ${ }^{\mathrm{a}} \mathrm{L}$. & Caricaceae \\
\hline
\end{tabular}


Table 3 (on next page)

Results of direct matrix ranking of agroforestry multipurpose woody species. 


\begin{tabular}{|c|c|c|c|c|c|c|c|}
\hline \multirow[t]{2}{*}{ Plant species } & \multicolumn{5}{|c|}{ Main Use Category } & \multirow{2}{*}{$\begin{array}{l}\text { Tot } \\
\text { al }\end{array}$} & \multirow{2}{*}{$\begin{array}{l}\text { Ra } \\
\text { nk }\end{array}$} \\
\hline & $\begin{array}{l}\text { Soil } \\
\text { fertility }\end{array}$ & $\begin{array}{l}\text { Wild } \\
\text { edible }\end{array}$ & $\begin{array}{l}\text { Construction } \\
\& \text { farm tools }\end{array}$ & $\begin{array}{l}\text { Charcoal \& } \\
\text { fire wood }\end{array}$ & $\begin{array}{l}\text { Shade \& } \\
\text { Fence }\end{array}$ & & \\
\hline Carissa spinarum & 2 & 5 & 1 & 4 & 4 & 16 & 6 \\
\hline Cordia africana & 3 & 3 & 5 & 5 & 5 & 21 & 1 \\
\hline Croton macrostychus & 4 & 0 & 5 & 5 & 5 & 19 & 3 \\
\hline Ficus sur & 3 & 5 & 4 & 2 & 5 & 19 & 3 \\
\hline Ficus vasta & 3 & 4 & 4 & 2 & 5 & 18 & 4 \\
\hline Hagenia abyssinica & 5 & 0 & 5 & 5 & 5 & 20 & 2 \\
\hline $\begin{array}{l}\text { Syzygium guineense } \\
\text { subsp. guineense }\end{array}$ & 1 & 5 & 3 & 5 & 3 & 16 & 5 \\
\hline
\end{tabular}

1 


\section{Table 4 (on next page)}

Use values of the most important multipurpose tree species with more than two use categories. 


\begin{tabular}{|c|c|c|c|c|c|}
\hline Name of species & $\begin{array}{l}\text { Use } \\
\text { category }\end{array}$ & $\begin{array}{ll}\text { No. } & \text { of } \\
\text { informants } & \end{array}$ & $\begin{array}{l}\text { Use } \\
\text { citations }\end{array}$ & $\begin{array}{l}\text { Use } \\
\text { value }\end{array}$ & Rank \\
\hline Albizia schimperiana & 5 & 36 & 180 & 1.8 & 5 \\
\hline Cordia africana & 6 & 36 & 216 & 2.2 & 4 \\
\hline Croton macrostachyus & 5 & 43 & 215 & 2.2 & 4 \\
\hline Erythrina brucei & 3 & 20 & 60 & 0.6 & 10 \\
\hline Ficus sur & 3 & 27 & 81 & 0.8 & 8 \\
\hline Ficus vasta & 3 & 24 & 72 & 0.7 & 9 \\
\hline Hagenia abyssinica & 5 & 48 & 240 & 2.4 & 3 \\
\hline Juniperus procera & 5 & 48 & 240 & 2.4 & 3 \\
\hline Millettia ferruginea & 5 & 20 & 100 & 1.0 & 7 \\
\hline Myrica salicifolia & 5 & 35 & 175 & 1.8 & 5 \\
\hline Olea europaea subsp. cuspidata & 7 & 43 & 301 & 3.0 & 2 \\
\hline Podocarpus falcatus & 4 & 28 & 112 & 1.1 & 6 \\
\hline Sesbania sesban & 5 & 20 & 100 & 1.0 & 7 \\
\hline $\begin{array}{l}\text { Syzygium gineense subsp. } \\
\text { afromontanum }\end{array}$ & 5 & 20 & 100 & 1.0 & 7 \\
\hline Vachellia abyssinica & 6 & 65 & 390 & 3.9 & 1 \\
\hline
\end{tabular}




\section{Table 5 (on next page)}

Error matrices resulting from classifying test pixels for the classified images of 1985 (a), 2001 (b), and 2019 (c).

The producer value represents the reference data whereas the user value represents the classification generated from the remotely sensed data. Bolded diagonal numbers represent correctly classified sites according to reference data, whereas off-diagonals represent misclassified values concerning reference data. 


\begin{tabular}{|c|c|c|c|c|c|c|c|c|}
\hline 1985(a) & $\begin{array}{l}\text { Agroforestry } \\
\text { Cover }\end{array}$ & Cropland & $\begin{array}{l}\text { Forest } \\
\text { Cover }\end{array}$ & $\begin{array}{l}\text { Settlement } \\
\text { and roads }\end{array}$ & $\begin{array}{l}\text { Shrub } \\
\text { Cover }\end{array}$ & $\begin{array}{l}\text { Water } \\
\text { body }\end{array}$ & $\begin{array}{l}\text { User } \\
\text { value }\end{array}$ & $\begin{array}{l}\text { User's } \\
\text { accuracy } \\
\text { (\%) }\end{array}$ \\
\hline $\begin{array}{l}\text { Agroforestry } \\
\text { Cover }\end{array}$ & 42 & 0 & 0 & 0 & 2 & 0 & 44 & 95.5 \\
\hline Cropland & 1 & 46 & 0 & 0 & 0 & 1 & 48 & 95.8 \\
\hline Forest Cover & 0 & 0 & 42 & 0 & 0 & 0 & 42 & 100 \\
\hline $\begin{array}{l}\text { Settlement and } \\
\text { roads }\end{array}$ & 0 & 1 & 0 & 47 & 1 & 0 & 49 & 95.9 \\
\hline Shrub Cover & 1 & 0 & 0 & 0 & 31 & 1 & 33 & 93.9 \\
\hline Water body & 0 & 0 & 0 & 0 & 0 & 12 & 12 & 100 \\
\hline Producer value & 44 & 47 & 42 & 47 & 34 & 14 & 228 & \\
\hline $\begin{array}{l}\text { Producer's } \\
\text { accuracy (\%) } \\
\text { Overall } \\
\text { Accuracy (\%) } \\
\text { Kappa statistic }\end{array}$ & $\begin{array}{l}95.5 \% \\
96.5 \\
96 \%\end{array}$ & 97.9 & 100 & 100 & 91.2 & 85.7 & & \\
\hline $2001(b)$ & & & & & & & & \\
\hline $\begin{array}{l}\text { Agroforestry } \\
\text { Cover }\end{array}$ & 18 & 1 & 0 & 0 & 0 & 0 & 19 & 94.7 \\
\hline Cropland & 2 & 46 & 0 & 1 & 1 & 0 & 50 & 92.0 \\
\hline Forest Cover & 0 & 0 & 44 & 0 & 6 & 0 & 50 & 88.0 \\
\hline $\begin{array}{l}\text { Settlement and } \\
\text { roads }\end{array}$ & 0 & 2 & 0 & 25 & 0 & 0 & 27 & 92.6 \\
\hline Shrub Cover & 0 & 1 & 1 & 0 & 44 & 0 & 46 & 95.7 \\
\hline Water body & 0 & 3 & 0 & 0 & 0 & 22 & 25 & 88.0 \\
\hline Producer value & 20 & 53 & 45 & 26 & 51 & 22 & 217 & \\
\hline $\begin{array}{l}\text { Producer's } \\
\text { accuracy (\%) } \\
\text { Overall } \\
\text { Accuracy (\%) } \\
\text { Kappa statistic }\end{array}$ & $\begin{array}{l}90.0 \\
91.7 \\
90.0 \%\end{array}$ & 86.8 & 97.8 & 96.2 & 86.3 & 100 & & \\
\hline 2019(c) & & & & & & & & \\
\hline $\begin{array}{l}\text { Agroforestry } \\
\text { Cover }\end{array}$ & 62 & 1 & 3 & 0 & 2 & 0 & 68 & 91.2 \\
\hline Cropland & 2 & 68 & 1 & 0 & 1 & 0 & 72 & 94.4 \\
\hline Forest Cover & 0 & 0 & 22 & 0 & 0 & 0 & 22 & 100 \\
\hline $\begin{array}{l}\text { Settlement and } \\
\text { roads }\end{array}$ & 0 & 10 & 0 & 100 & 0 & 0 & 110 & 90.9 \\
\hline Shrub Cover & 0 & 1 & 2 & 0 & 49 & 0 & 52 & 94.2 \\
\hline Water body & 0 & 0 & 0 & 0 & 0 & 19 & 19 & 100 \\
\hline Producer value & 64 & 80 & 28 & 100 & 52 & 19 & 343 & \\
\hline $\begin{array}{l}\text { Producer's } \\
\text { accuracy (\%) }\end{array}$ & 96.9 & 85 & 78.6 & 100 & 94.2 & 100 & & \\
\hline $\begin{array}{l}\text { Overall } \\
\text { Accuracy (\%) }\end{array}$ & 93.3 & & & & & & & \\
\hline Kappa statistic & $92.0 \%$ & & & & & & & \\
\hline
\end{tabular}


Table 6(on next page)

Summary of area change in percentage for six classes of LULC categories. 


\begin{tabular}{lllllll}
\hline LULC Class & $\mathbf{1 9 8 5}-\mathbf{2 0 0 1}$ & & $\mathbf{2 0 0 1 - 2 0 1 9}$ & \multicolumn{3}{c}{ 1985-2019 } \\
\hline & Area (ha) & Area (\%) & Area (ha) & Area (\%) & Area (ha) & Area (\%) \\
Agroforestry & 115.64 & 0.3 & 1635.97 & 3.5 & 1751.61 & 3.8 \\
cover & & & & & & \\
Cropland & -1445.25 & -3.1 & -5064.96 & -10.8 & -6510.21 & -13.9 \\
Forest cover & -365.61 & -0.8 & -3153.41 & -6.8 & -3519.03 & -7.5 \\
Settlement & -531.62 & -1.1 & 9453.07 & 20.2 & 8921.46 & 19.1 \\
and road & & & & & & \\
Shrub cover & 2287.26 & 4.9 & -2800.96 & -6.0 & -513.70 & -1.1 \\
Water body & -60.41 & -0.1 & -69.71 & -0.2 & -130.12 & -0.3 \\
\hline
\end{tabular}

1 